\title{
Records of Neomorphus squamiger todd, 1925 (cuculiforme: cuculidae) and interaction between $n$. Squamiger and a flock of Tayassu pecari link, 1795 (artiodactyla: tayassuidae)
}

\author{
Gonçalves-Castro, $V^{a, b *}$ and Silva-Castilho, L. $^{a}$ \\ ${ }^{a}$ Biota Projetos e Consultoria Ambiental, Rua 86 C, 64, Setor Sul, CEP 74083-360, Goiânia, GO, Brazil \\ borganização de Desenvolvimento Sustentável - ODS, Rua Eduardo de Noronha, 298, Bairro Sobradinho, \\ CEP 38701-120, Patos de Minas, MG, Brazil \\ *e-mail: biologovictorcastro@gmail.com
}

Received: May 2, 2014 - Accepted: July 14, 2014 - Distributed: August 31, 2015

Scaled Ground Cuckoo (Neomorphus squamiger Todd 1925) is a bird belonging to the order Cuculiformes in the Cuculidae family (CBRO, 2014). The species is endemic to the Xingu and Tapajós rivers interfluves. It inhabits onshore forests and preserved rainforests (Sigrist, 2013). The records are limited to some few specimens collected and visual and auditory records (Parker III et al., 1996; Payne, 1997). Their behavioral habits are virtually unknown to science (Sigrist, 2013). Scaled Ground Cuckoo is considered vulnerable in the "Red List" (BirdLife International, 2012) and described as rare (Stotz et al., 1996). Species is dependent on forest areas (BirdLife International, 2012), the main threat to destruction of their natural habitat (Soares-Filho et al., 2006).

$N$. squamiger was first described as a species and later considered as subspecies Neomorphus geoffroyi Temminck 1820 (Payne 1997; Sick, 2001) by small genetic difference between them. Currently it is considered a full species (CBRO, 2014), by having distinct plumage. Thus, the importance of each record of $N$. squamiger justified for all matters of taxonomic changes, lack of ecological data, rarity and threat of records. Therefore, the current work complements a small part of this deficiency presenting new records of occurrence and behavior.

About the new records of $N$. squamiger in chronological order: Lees (2003) recorded in the Cristalino Jungle Lodge Private Reserve of Natural Heritage (RPPN) in Alta Floresta - Mato Grosso/Brazil, on 07 June/2003. At the same location Lambert (2004) recorded an individual on May $4^{\text {th }}, 2004$. On September $21^{\text {th }}, 2012$, Battistuzzo (2012) made a sound recording in Cristalino Lodge Reserve (RPPN).

In Altamira-Pará/Brazil, Castro (2013) recorded the species on March 24 $4^{\text {th }}, 2013$. In Vitória do Xingú, on May $24^{\text {th }}, 2013$, Fernandes $(2013)$ recorded the species on May $28^{\text {th }}, 2013$. On August $10^{\text {th }}, 2013$, Lopes (2013) photographed and recorded a couple of species in the Cristalino Lodge RPPN. In the same place Riegner (2013) recorded the species in September $3^{\text {rd }}, 2013$.

Regarding the interaction between $N$. squamiger and a flocks of Tayassu pecari Link 1795 (white-lipped peccary), the September 15 $5^{\text {th }}, 2013$ in Vitória do Xingú-Pará/Brazil, biologist Victor G. Castro filmed an individual interacting on a stick about 40 peccaries. He was with the last individuals stick while pigs were foraging. Such behavior has been described for Neomorphus geoffroyi Temminck 1820 (Rufous-vented Ground Cuckoo) (Sigrist, 2013) but had not been described for $N$. squamiger yet. As described by Sick (2001), the animal runs in the forest ground, resembling a caxinguelê (Sciurus aestuans Linnaeus, 1766).

Rufous-vented Ground Cuckoo is a bit conspicuous bird. In an interval of 11 years (between 2003 and 2014), only a few records are known and are presented in this work. It reflects the matter of each record of this species. Therefore, the new information presented here contributes to a better understanding the distribution and behavioral biology of this bird little known to science.

\section{References}

BATTISTUZZO, G., 2012. WA960688, Neomorphus squamiger Todd, 1925. Wikiaves: a enciclopédia das aves do Brasil. Available from: <http://www.wikiaves.com.br/960688>. Access in: 19 Apr. 2014

BirdLife International, 2012. Falco deiroleucus. IUCN Red List of Threatened Species. IUCN. Available from: <http://www. iucnredlist.org/details/22696516/0>. Access in: 18 Apr. 2014.

CASTRO, VG., 2013. WA1088098, Neomorphus squamiger Todd, 1925. Wikiaves: a enciclopédia das aves do Brasil. Available from: $<$ http://www.wikiaves.com/1088098>. Access in: 19 Apr. 2014.

Comitê Brasileiro de Registros Ornitológicos - CBRO, 2014. Listas das aves do Brasil. 11th ed. Available from: $<\mathrm{http} / / \mathrm{www}$. cbro.org.br>. Access in: 15 Apr. 2014.

FERNANDES, D., 2013. WA992391, Neomorphus squamiger Todd, 1925. Wikiaves: a enciclopédia das aves do Brasil. Available from: $<$ http://www.wikiaves.com.br/992391>. Access in: 19 Apr. 2014.

LAMBERT, F., 2004. XC68839, Neomorphus squamiger Todd, 1925. Xeno-canto: compartilhando sons de aves do mundo todo. Available from: <http://www.xeno-canto.org/68839>. Access in: 19 Apr. 2014.

LEES, A., 2003. XC169437, Neomorphus squamiger Todd, 1925. Xeno-canto: compartilhando sons de aves do mundo todo. 
Available from: $<$ http://www.xeno-canto.org/8791 $>$. Access in: 19 Apr. 2014.

LOPES, J., 2013. WA1203910, Neomorphus squamiger Todd, 1925. Wiki Aves: a enciclopédia das aves do Brasil. Available from: $<$ http://www.wikiaves.com/1203910>. Access in: 19 Apr. 2014.

PARKER III, TA., STOTZ, DF. and FITZPATRICK, JW., 1996. Ecological and distributional databases. In STOTZ, DF., FITZPATRICK, JW., PARKER III, TA. and MOSKOVITS, DK. (Eds.). Neotropical bird ecology and conservation. Chicago: University of Chicago Press. p. 113-436.

PAYNE, RB., 1997. Cuculidae (Cuckoos). In DEL HOYO, J., ELLIOTT, A. and SARGATAL, J. (Eds.). Handbook of the birds of the world. Barcelona: Lynx Edicions. p. 508-607.

RIEGNER, M., 2013. XC169437, Neomorphus squamiger Todd, 1925. Xeno-canto: compartilhando sons de aves do mundo todo. Available from: <http://www.xeno-canto.org/169437>. Access in: 19 Apr. 2014.
SICK, H., 2001. Ornitologia brasileira. Rio de Janeiro: Nova Fronteira. p. 390-391.

SIGRIST, T., 2013. Guia de campo Avis Brasilis: Avifauna Brasileira. São Paulo: AvisBrasilis. 200 p.

SOARES-FILHO, BS., NEPSTAD, DC., CURRAN, LM., CERQUEIRA, GC., GARCIA, RA., RAMOS, CA., VOLL, E., MCDONALD, A., LEFEBVRE, P. and SCHLESINGER, P., 2006. Modelling conservation in the Amazon basin. Nature, vol. 440, no. 7083 , p. 520-523. http://dx.doi.org/10.1038/nature04389. PMid:16554817.

STOTZ, DF., FITZPATRICK, JW., PARKER III, TA. and MOSKOVITS, DK., 1996. Neotropical birds: ecology and conservation. Chicago: University of Chicago Press. 